\title{
Computational technology of daily blood pressure monitoring results comparison in patients with arterial hypertension
}

\author{
0. M. Matsuga ${ }^{1}$, I. V. Drozdova² ${ }^{2}$ A. K. Akimova ${ }^{1}$ \\ ${ }^{1}$ Oles Honchar Dnipro National University, Ukraine, ${ }^{2}$ State Institution "Ukrainian State Scientific and Research Institute \\ of Medical and Social Problems of Disability MoH of Ukraine", Dnipro
}

The evaluation of treatment effectiveness and further patient with arterial hypertension (AH) monitoring require the target level of arterial pressure achievement and its control by means of daily monitoring of blood pressure (DMBP).

Purpose of the work involves development, software implementation and practical approval of computational technology in order to compare the results of patient's two daily monitoring of blood pressure.

Material and methods. The open controlled study included 10 patients with $\mathrm{AH}$ at the third stage in long term after a cerebral stroke. Patients were treated according to the regulatory basis. DBPM was conducted using device ABPM-01 (Meditech, Hungary) twice (before the treatment and after 1 year). Results comparison of the first and repeated DMBP was carried out by means of proposed computational technology and its own software ArtHyper in which the technology was implemented. The technology is based on the comparison of DMBP indices distribution functions using the two-sample Kolmogorov test and the Wilcoxon test.

Results. The proposed technology work was demonstrated in terms of two patients. The target level of arterial pressure was achieved only for the first patient. The majority of DMBP indices distribution for this patient did not change in a year, in other words, the blood pressure and heart rate remained stable due to the treatment. The level of PBP slightly decreased, but in this case it was a positive factor. The second patient didn't follow the complete course of treatment and didn't achieve the target level of blood pressure. His levels of diastolic blood pressure and heart rate increased.

Conclusions. The computational technology of two patient's DMBP results comparison was developed. Its practical testing was carried out on real data and demonstrated the effectiveness of technology to detect changes in the second results monitoring and the possibility of its application for the evaluation of rehabilitation and treatment efficiency in patients with arterial hypertension.

\section{Обчислювальна технологія порівняння результатів добового моніторування артеріального тиску в пацієнтів з артеріальною гіпертензією}

\section{О. М. Мацуга, І. В. Ароздова, А. К. Акімова}

Оцінювання ефективності лікування та контроль за станом пацієнта з артеріальною гіпертензією (АГ) потребують досягнення цільового рівня артеріального тиску (АТ) і його підтвердження за допомогою добового моніторування артеріального тиску (ДМАТ).

Мета роботи - розробка та програмна реалізація обчислювальної технології для порівняння результатів двох ДМАТ пацієнта, а також практична апробація технології на реальних даних

Матеріали та методи. Відкрите контрольоване дослідження охоплювало 10 хворих на АГ III ст. у віддалений термін після перенесеного мозкового інсульту. Лікування хворих здійснювали згідно з нормативною базою. ДМАТ виконали на апараті ABPM-1 (Meditech, Угорщина) двічі (до початку лікування і через 1 рік). Результати першого та повторного ДМАТ порівняли за допомогою запропонованої обчислювальної технології та власного програмного забезпечення ArtHyper, в якому її реалізували. Технологія базується на порівнянні функцій розподілів показників ДМАТ за допомогою двовибіркового критерію Колмогорова та критерію Вілкоксона.

Результати. Роботу технології продемонстрували на прикладі двох пацієнтів, в одного з них вдалося досягти цільового рівня АТ. У першого пацієнта розподіл більшості показників ДМАТ через рік не змінився, тобто завдяки лікуванню рівень АТ і частота серцевих скорочень хворого залишилися на стабільному рівні, дещо зменшився рівень ПАТ, але це позитивний фактор. У другого пацієнта, який не дотримувався призначеного лікування й не досяг цільового рівня АТ, підвищились рівень діастолічного АТ і частота серцевих скорочень.

Висновки. Розробили обчислювальну технологію порівняння результатів двох ДМАТ пацієнта. Виконали ї̈ практичну апробацію на реальних даних, що засвідчила ефрективність технології для виявлення змін у результатах повторного моніторування та можливість їі застосування для оцінювання результативності реабілітації та лікування хворих на артеріальну гіпертензію.

\section{Вычислительная технология сравнения результатов суточного мониторирования артериального давления у пациентов с артериальной гипертензией}

\section{О. Н. Мацуга, И. В. Ароздова, А. К. Акимова}

Оценка эффективности лечения и контроль за состоянием больного артериальной гипертензией (АГ) требуют достижения целевого уровня артериального давления (АД) и его проверки с помощью суточного мониторирования артериального давления (СМАД).

Цель работы - разработка и программная реализация вычислительной технологии для сравнения результатов двух СМАД пациента, а также практическая апробация технологии на реальных данных.

Кнючові слова:

Аобове моніторування артеріального тиску, обчислювальна технологія, порівняння результатів.

Запорізький медичний журнал. - 2018. T. 20, № 3(108). C. 309-314

Киючевые слова: суточное мониторирование артериального Аавления, вычислительная технология, сравнение результатов. 
Запорожский медицинский журнал. - 2018. -

T. 20, № 3(108), C. $309-314$

Материалы и методы. Открытое контролируемое исследование охватывало 10 больных артериальной гипертензией III стадии в отдаленный срок после перенесенного мозгового инсульта. Лечение больных осуществляли согласно нормативной базе. СМАД проводили на аппарате АВРM-01 (Meditech, Венгрия) дважды (до начала лечения и через 1 год). Результаты первого и повторного СМАД сравнивали с помощью предложенной вычислительной технологии и собственного программного обеспечения ArtHyper, в котором ее реализовали. Технология базируется на сравнении функций распределения показателей СМАД с помощью двухвыборочного критерия Колмогорова и критерия Вилкоксона.

Результаты. Работу предложенной технологии продемонстрировали на примере двух пациентов, у одного из которых удалось достичь целевого уровня АД. У первого пациента распределение большинства показателей СМАД через год не изменилось, то есть благодаря лечению уровень АД и частота сердечных сокращений больного остались на стабильном уровне, несколько изменился уровень ПАД, но это было позитивным фактором. У второго пациента, который не придерживался назначенного лечения и не достиг целевого уровня АД, выросли уровень диастолического АД и частота сердечных сокращений.

Выводы. Разработана вычислительная технология сравнения двух СМАД пациента. Проведена ее практическая апробация на реальных данных, которая подтвердила эффективность технологии для установления изменений в результатах повторного мониторирования и возможность ее применения для оценки результативности реабилитации и лечения больных артериальной гипертензией.

Daily monitoring of blood pressure (DMBP) is a modern and effective method used for diagnosis and evaluation the effectiveness of arterial hypertension treatment (AH) $[2,4-6]$. Currently, the methods and software have been developed for analysis of DMBP results with the purpose of arterial hypertension diagnosis $[3,4,7,8]$. However, the treatment effectiveness and the further patient's condition assessment require blood pressure re-monitoring and comparison of these results with previously obtained ones. Usually the comparison is limited to DMBP indices values comparison. But differences in the values can be insignificant and caused by chance. So, such kind of comparison cannot be considered as acceptable. This work is aimed at developing a more effective and objective technology in order to compare a patient's two DMBP results.

\section{Purpose}

Purpose of the work involves development, software implementation and practical approval of computational technology in order to compare the results of patient's two daily monitoring of blood pressure.

\section{Materials and methods}

10 patients were examined in the State Institution "Ukrainian State Scientific and Research Institute of Medical and Social Problems of Disability". Inclusion criterion for study was essential hypertension at the $3^{\text {rd }}$ stage in patients aged 30-59 years. Exclusion criterions were secondary form of arterial hypertension, renal artery stenosis, permanent atrial fibrillation, severe disturbances of liver and kidneys functions, myocardial infarction, cardiosurgical interventions, uncompensated diabetes, presence of comorbidities that could affect the survival and quality of patients life within 3 months, treatment refusal. All patients received information for patients and signed an agreement on consent to participate in the study.

Arterial hypertension was diagnosed according to the requirements of the normative documents currently in force: "Resolution and Clinical Report of Medical Care: Arterial Hypertension", guidelines of the Ukrainian Association of Cardiologists (2013), guidelines of the European Society of Cardiology (2013), adapted clinical resolution "Modern Principles of Diagnosis and Treatment of Patients with Acute Ischemic Stroke and TIA" and unified clinical report of medical care "Ischemic Stroke".

DMBP was conducted in all patients by means of the conventional method using device ABPM-01 (Meditech, Hungary) [4-6]. During the day five parameters were recorded: systolic blood pressure (SBP), diastolic blood pressure (DBP), pulse blood pressure (PBP), average blood pressure $(\mathrm{BP})$ and heart rate $(\mathrm{HR})$. The measurements were carried out in the following way: during the day - every 15 minutes and at night (from 22.00 to 6.00) - every 30 minutes. Patients led a normal lifestyle and experienced regular physical and psycho-emotional stresses [4-6].

One year later DBPM was carried out using the same device.

The question arises as to whether patients' condition has changed in a year, and whether medical treatment was effective.

The computational technology to compare the first and second DMBP patient's results was suggested in order to have this question answered.

The following considerations were used in the technology development. DMBP indices for processing are not constant throughout the day. Firstly, they fluctuate due to physiological factors, for example, blood pressure at night is always lower, and secondly, they are influenced by random external factors such as stress, weather changes and so on. In view of the random effects, DMBP indices can be recognized as random values and hereby it is possible to consider their probability distribution. Then, in order to check the changes in DMBP indices of the patient after re-examination, it is advisable to check whether the distribution function changes. These considerations make it possible to suggest the computational technology to compare the distribution functions of the DMBP indices.

For each of the five DMBP indices the computational technology involves the following steps:

1. To build an empirical distribution functions $[1,9]$ for the selected index according to the information of the $1^{\text {st }}$ and $2^{\text {nd }}$ blood pressure monitoring.

2. To compare the distribution functions of the indices during the $1^{\text {st }}$ and $2^{\text {nd }}$ monitoring by means of the two-sample Kolmogorov test $[1,9]$. If provided by the given significance level a inequality $\mathrm{P}<\mathrm{a}$ holds true, it can be argued that distribution function of the index during the $2^{\text {nd }}$ monitoring 


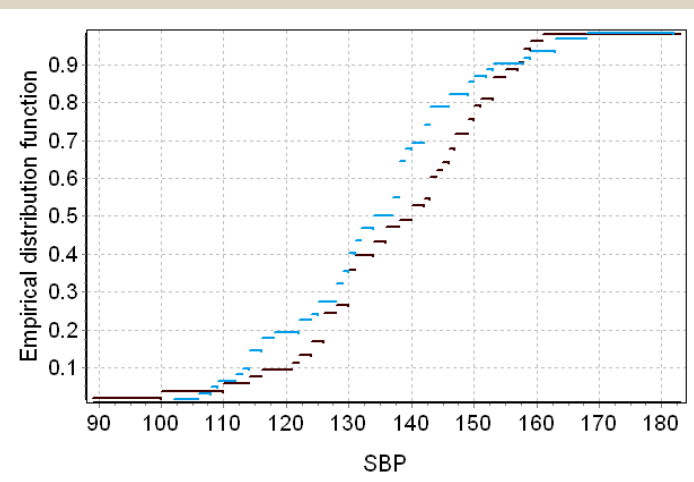

Empirical distribution function of SBP

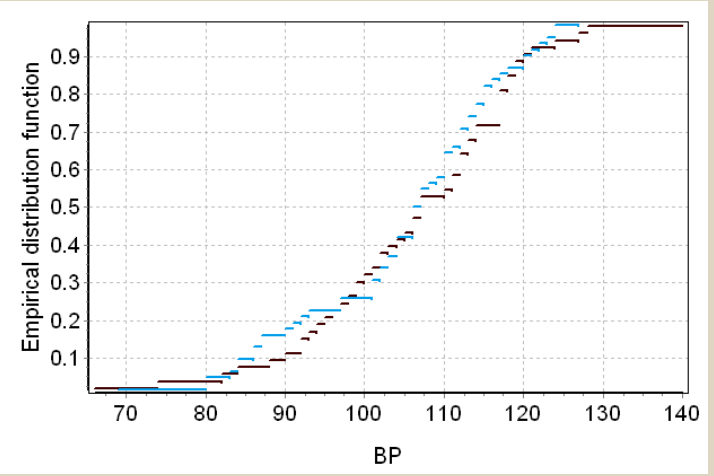

Empirical distribution function of BP

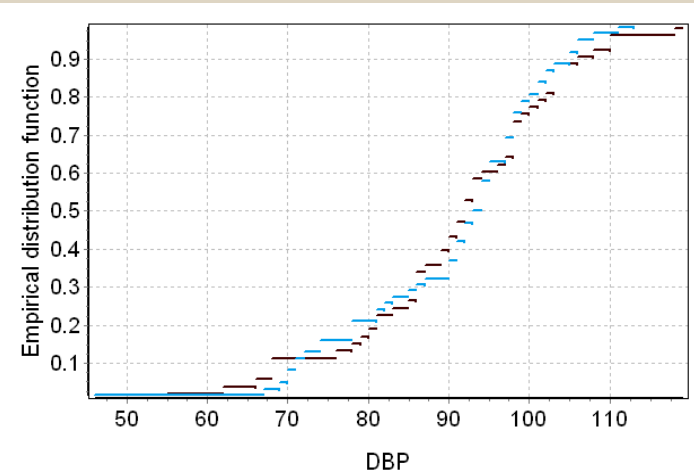

Empirical distribution function of DBP

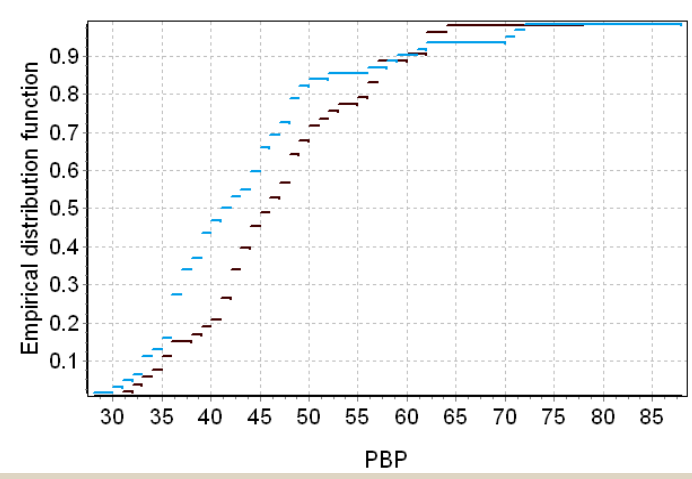

Empirical distribution function of PBP

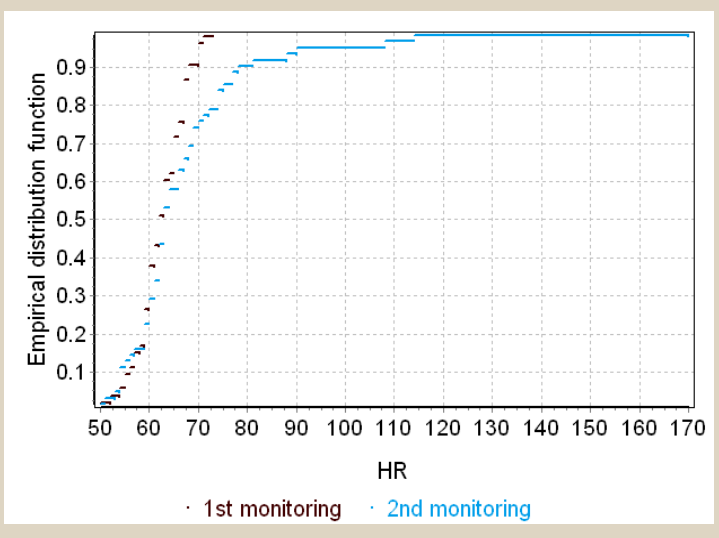

Empirical distribution function of $\mathrm{HR}$

Fig. 1. Empirical distribution functions of the indices of the $1^{\text {st }}$ and $2^{\text {nd }} D M B P$ for the first patient.

significantly differs from the function that took place during the $1^{\text {st }}$ monitoring. In this case one shall proceed to step 3. Otherwise, it is assumed that the distribution function doesn't change.

3. To check whether the differences in the distribution functions of indices are explained by the shift and, if so, the distribution function for the $2^{\text {nd }}$ monitoring is shifted left or right relative to the distribution function for the $1^{\text {st }}$ monitoring. For this purpose it is possible to apply the non-parametric statistical test such as the Wilcoxon test [1,9].

The proposed computational technology is implemented in its own software ArtHyper written in the C\# programming language in the environment Microsoft Visual Studio 2012.

\section{Results and discussion}

By means of ArtHyper software the practical testing of the proposed technology on real data was conducted. As an example, the results are provided below for two patients - one, who followed the prescribed medical treatment, and the other, who didn't follow it completely. During the application of all the tests, $a=0.05$ was used. The empirical distribution functions of the SBP, DBP, PBP, BP, HR were constructed for the patient who followed the prescribed medical treatment in accordance with the $1^{\text {st }}$ and repeated DMBP, see Fig. 1.

According to the two-sample Kolmogorov test results, the distribution functions of PBP for two monitoring processes differed significantly and for the other indices 


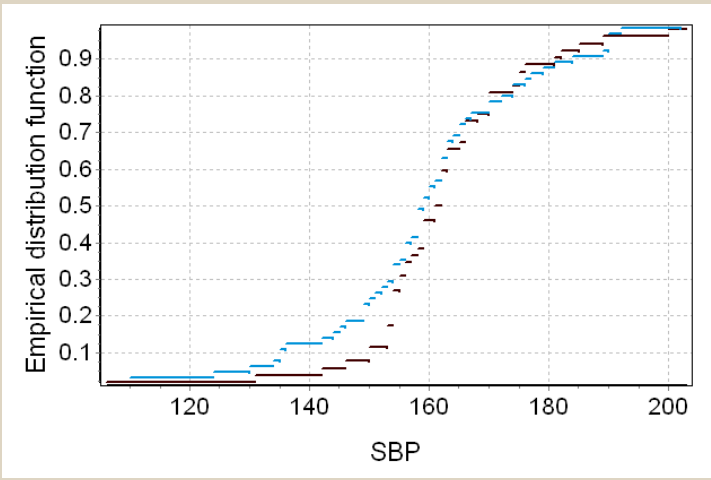

Empirical distribution function of SBP

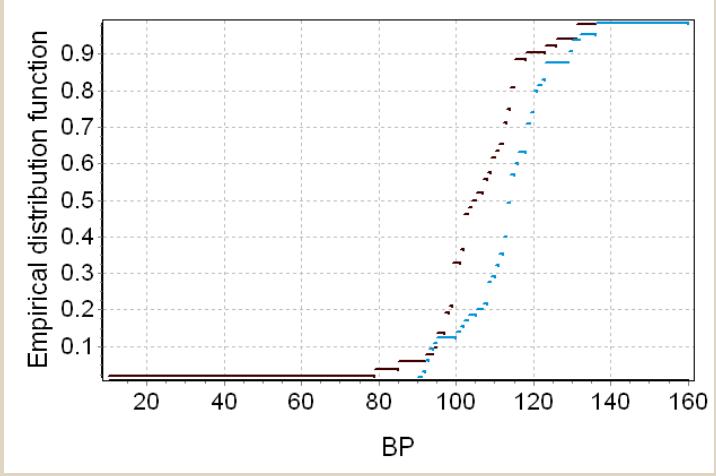

Empirical distribution function of $\mathrm{BP}$

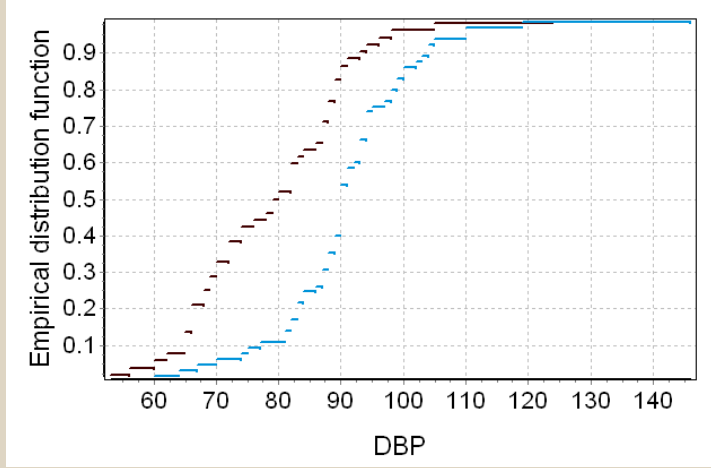

Empirical distribution function of DBP

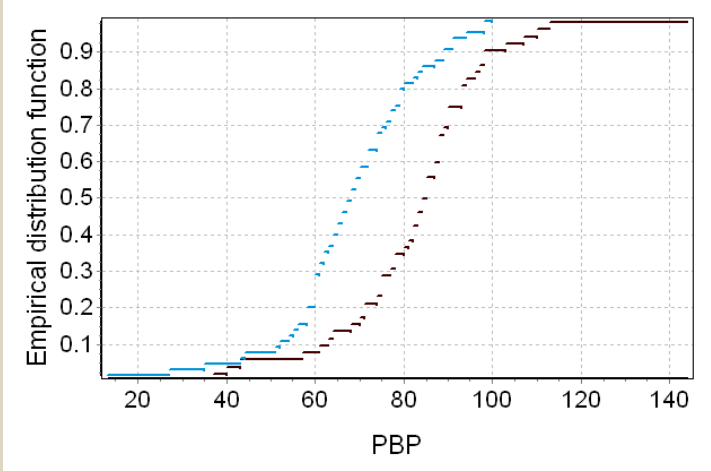

Empirical distribution function of PBP

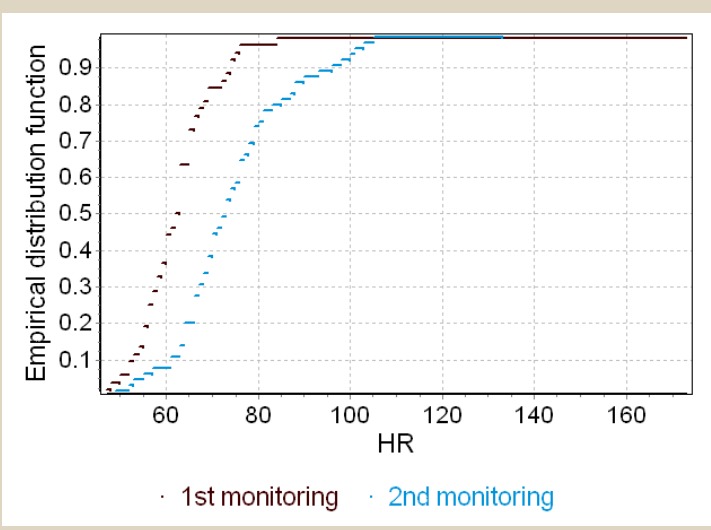

Empirical distribution function of HR

Fig. 2. Empirical distribution functions of the indices of the $1^{\text {st }}$ and $2^{\text {nd }}$ DMBP for the second patient.

they were equal (Table 1). According to the Wilcoxon test results (Table 2), the distribution function of PBP obtained during the second DMAT shifted left as compared to another that took place during the first patient's examination. This indicated that the PBP level had declined in a year.

Consequently, most of the DMAT indices distribution for this patient did not change in a year, in other words, the blood pressure and heart rate of the patient remained stable due to the treatment. The level of PBP slightly decreased, but in this case it was a positive factor.

For the patient who didn't follow the complete course of treatment the empirical distribution functions of the SBP, $\mathrm{DBP}, \mathrm{PBP}, \mathrm{BP}, \mathrm{HR}$ were constructed according to the $1^{\text {st }}$ and repeated DMAT, see Fig. 2.
Results of the indices distribution comparison by means of the two-sample Kolmogorov test suggest that the distribution of SBP in a year remained unchanged and the distribution of four other indices changed (Table 3). Herewith in accordance with the Wilcoxon test results (Table 4), we might as well say that the distribution functions of DBP, BP and HR in a year turned out to be shifted right in comparison with those that occurred at the beginning. Consequently, the level of these indices increased in a year. The distribution function of PBP turned out to be shifted left, that sounds logically in this case.

Thus in a year the patient's condition became worse. The levels of diastolic blood pressure and heart rate increased. 
A similar study was conducted for another 8 patients. The conclusions regarding the condition of all 10 patients derived from the application of the proposed technology of the $1^{\text {st }}$ and repeated DMBP results comparison were confirmed by an additional medical patients' examination. The conclusions were confirmed to be correct and justified. This suggests that the technology may be effective for the evaluation of rehabilitation and treatment efficiency.

\section{Conclusions}

The computational technology of two patient's DMBP results comparison was developed and implemented in its own software ArtHyper. The technology is based on distribution functions of the DMBP indices comparison using the twosample Kolmogorov test and the Wilcoxon test. Its practical testing was carried out on real data and demonstrated the effectiveness of technology to detect changes in the second results monitoring and the possibility of its application for the evaluation of rehabilitation and treatment.

Further researches can be directed to carry out computational technology practical testing for a large number of patients.

Conflicts of Interest: authors have no conflict of interest to declare. Конфлікт інтересів: віАсутній.

Information about authors:

Matsuga 0. M., PhD, Associate Professor of the Department of Mathematical Support of Calculating Machines Department, Oles Honchar Dnipro National University, Ukraine.

Drozdova I. V., MD, PhD, DSci, Head of the Department of MedicoSocial Examination and Rehabilitation in Internal, Nervous Diseases and Psychosomatic Disorders, State Institution "Ukrainian State Institute of Medical and Social Problems of Disability Ministry of Public Health of Ukraine", Dnipro. Akimova A. K., Graduate Student, Oles Honchar Dnipro National University, Ukraine.

Відомості про авторів:

Мацуга О. М., канд. техн. наук, Аоцент каф. математичного забезпечення ЕОМ, Аніпровський національний університет імені Олеся Гончара, Україна.

АрозАова І. В., А-р меА. наук, старший науковий співробітник, керівник відАілу медико-соціальної експертизи та реабілітації при внутрішніх, нервових хворобах і психосоматичних розлаАах, АУ “Український Аержавний науково-АосліАний інститут меАико-соціальних проблем інвалідності МОЗ України”, м. Аніпро.

Акімова А. К., магістрант Аніпровського національного університету імені Олеся Гончара, Україна.

Сведения об авторах:

Мацуга О. Н., канА. техн. наук, Аоцент каф. математического обеспечения ЭВМ, Анипровский национальный университет имени Олеся Гончара, Украина.

Ароздова И. В., А-р меА. наук, старший научный сотрудник, руководитель отАела меАико-социальной экспертизы и реабилитации при внутренних, нервных болезнях и психосоматических расстройствах, ГУ „Украинский государственный научно-исследовательский институт меАикосоциальных проблем инвалидности МЗО Украины", г. Анипро. Акимова А. К., магистрант Анипровского национального университета имени Олеся Гончара, Украина.

Надійшла до реАакції / Received: 01.11.2017

Після Аоопрацювання / Revised: 14.11.2017

Прийнято Ао Аруку / Accepted: 05.12.2017
Table 1. The two-sample Kolmogorov test results for the first patient

\begin{tabular}{|c|c|c|c|c|}
\hline Index & z & $K(z)$ & p & $\begin{array}{l}\text { Conclusions about the equality } \\
\text { of distribution functions of the indices } \\
\text { during the } 1^{\text {st }} \text { and } 2^{\text {nd }} \text { monitoring }\end{array}$ \\
\hline SBP & 1.041 & 0.771 & 0.229 & Distribution functions are equal \\
\hline DBP & 0.454 & 0.014 & 0.986 & Distribution functions are equal \\
\hline $\mathrm{BP}$ & 0.651 & 0.209 & 0.791 & Distribution functions are equal \\
\hline PBP & 1.391 & 0.958 & 0.042 & Distribution functions are different \\
\hline HR & 1.134 & 0.847 & 0.153 & Distribution functions are equal \\
\hline
\end{tabular}

Table 2. The Wilcoxon test results for the first patient

\begin{tabular}{|c|c|c|c|c|}
\hline Index & $w$ & $u$ & $p$ & $\begin{array}{l}\text { Conclusions about the shift } \\
\text { of distribution functions of the indices } \\
\text { during the } 1^{\text {st }} \text { and } 2^{\text {nd }} \text { monitoring }\end{array}$ \\
\hline SBP & 3327.5 & 1.422 & 0.155 & There is no shift \\
\hline DBP & 3067 & -0.039 & 0.969 & There is no shift \\
\hline $\mathrm{BP}$ & 3169.5 & 0.536 & 0.592 & There is no shift \\
\hline PBP & 3463 & 2.183 & 0.029 & Left shift \\
\hline HR & 2801 & -1.532 & 0.126 & There is no shift \\
\hline
\end{tabular}

Table 3. The two-sample Kolmogorov test results for the second patient

\begin{tabular}{l|l|l|l|l} 
Index & $\mathbf{z}$ & $\boldsymbol{K}(\mathbf{z})$ & $\boldsymbol{p}$ & $\begin{array}{l}\text { Conclusions about the equality } \\
\text { of distribution functions of the indices } \\
\text { during the } 1^{\text {st }} \text { and } \mathbf{2}^{\text {nd }} \text { monitoring }\end{array}$ \\
\hline SBP & 0.868 & 0.562 & 0.438 & Distribution functions are equal \\
\hline DBP & 2.295 & 1 & 0 & Distribution functions are different \\
\hline BP & 1.840 & 0.998 & 0.002 & Distribution functions are different \\
PBP & 2.439 & 1 & 0 & Distribution functions are different \\
\hline HR & 2.853 & 1 & 0 & Distribution functions are different \\
\hline
\end{tabular}

Table 4. The Wilcoxon test results for the second patient

\begin{tabular}{l|l|l|l|l} 
Index & $\boldsymbol{W}$ & $\boldsymbol{u}$ & $\boldsymbol{P}$ & $\begin{array}{l}\text { Conclusions about the shift of } \\
\text { distribution functions of the indices } \\
\text { during the } 1^{\text {st }} \text { and } \mathbf{2}^{\text {nd }} \text { monitoring }\end{array}$ \\
\hline SBP & 3234.5 & 0.913 & 0.361 & There is no shift \\
DBP & 2153.5 & -5.016 & 0 & Right shift \\
\hline BP & 2440 & -3.445 & 0.001 & Right shift \\
PBP & 3928 & 4.717 & 0 & Left shift \\
\hline HR & 2049 & -5.589 & 0 & Right shift \\
\hline
\end{tabular}

References

[1] Aivazyan, S. A., Yenyukov, I. S., \& Meshalkin, L. D. (1983). Prikladnaya statistika: Osnovy modelirovaniya i pervichnaya obrabotka dannykh [Applied statistics: Bases of modeling and initial data processing]. Moscow: Finansy i statistica. [in Russian].

[2] Vayda, L. S., Lozinska, N. V., Habriel, M. V., \& Gay, O. I. (2015). Pokaznyky dobovoho monitoruvannia arterialnoho tysku, lipidnoho spektra krovi, vazodylatatorna funktsiia endoteliiu ta indeks masy tila u khvorykh na arterialnu hipertenzilu na tii likuvannia karvedylolom i atenololom [The parameters of the 24 hours blood pressure monitoring, blood lipid spectrum, endothelial vasodilatator function and body mass index in patients with arterial hypertension under treatment with carvedilol and atenolol]. Ukrainskyi kardiolohichnyi zhurnal, 4, 55-60. [in Ukrainian].

[3] Dereza, A. Yu., \& Prystavka, P. O. (2005). Kuskovo-markivska model protsesu zminy arterialnoho tysku za chasom [Piecewise Markov model of changes in blood pressure over time]. Aktualni problemy avtomatyzatsii ta informatsiinykh tekhnolohii, 9, 3-12. [in Ukrainian].

[4] Dzyak, H. V., Kolesnyk T. V., \& Pohoretskyi, Yu. N. (2005). Sutochnoje monitorirovanie artetial'nogo davleniya [Daily blood pressure monitoring]. Dnipro. [in Russian].

[5] Mancia, G., Fagard, R., Narkiewicz, K., Redon, J., Zanchetti, A., Böhm, M., et al (2013) ESH/ESC guidelines for the management of arterial hypertension: the Task Force for the Management of Arterial Hypertension 
of the European Society of Hypertension (ESH) and of the European Society of Cardiology (ESC). Eur. Heart. J., 34(28), 2159-2219.

[6] Parati, G., Stergiou, G., O'Brien, E., Asmar R., Beilin, L., \& Bilo, G., et al. (2014). European Society of Hypertension practice guidelines for ambulatory blood pressure monitoring. J. Hypertens., 32(7), 1359-1366. doi: $10.1097 / \mathrm{HJH} .0000000000000221$.

[7] Khachapuridze, T. N. (2003). Modelirovanie monitoringa serdechno-sosudistoj sistemy [Modelling of monitoring of the cardiovascular system]. Aktualni problemy avtomatyzatsii ta informatsiinykh tekhnolohii, 7 . 142-149. [in Russian].

[8] Matsuga, O. M., \& Dereza, A. Yu. (2006). Realizatsiia sumishei rozpodiliv v avtomatyzovanii systemi ViStA Med [Implementation of mixtures of distributions in the automated system ViStAMed]. Aktualni problemy avtomatyzatsii ta informatsiinykh tekhnolohii, 10, 15-25. [in Ukrainian].

[9] Babak, V. P., Biletzkiy, A. J., Pristavka, O. P., \& Pristavka P. O. (2001). Statystychna obrobka danykh [Statistical processing of data]. Kyiv. [in Ukrainian]. 